\title{
Oesophageal atresia and associated anomalies
}

\author{
S CHITTMITTRAPAP, L SPITZ, E M KIELY, AND R J BRERETON
}

The Hospital for Sick Children, Great Ormond Street, London

SUMMARY Of 253 infants with oesophageal atresia treated over an eight year period, $122(48 \%)$ had a total of 213 other anomalies. Most commonly affected were the cardiovascular (61 cases, $29 \%$ ), anorectal (30 cases, $14 \%$ ), and genitourinary (29 cases, 14\%) systems. The VATER (or VACTERL) association was present in $10 \%$ of cases, but occurred more often in patients who had oesophageal atresia without an associated tracheo-oesophageal fistula $(3 / 13,23 \%)$. The level of the associated anorectal malformation was not associated with the type of oesophageal atresia. The presence and severity of other anomalies did not influence the basic approach to treatment of the oesophageal atresia - that is, primary repair whenever possible. Despite aggressive treatment, cardiac malformations were the most common cause of death. There were five infants with the CHARGE association, two with Potter's syndrome, and two with 'SCHISIS' syndrome (cleft lip and palate, omphalocoele, and hypogenitalism).

In infants with oesophageal atresia with or without tracheo-oesophageal fistula, the incidence of associated congenital abnormalities ranges from between $40-57 \%$ of patients. ${ }^{1-6}$ The well known occurrence of three or more of these anomalies, Vertebral defects, Anorectal malformation, TracheoEsophageal fistula, Renal anomaly, and Radial dysplasia, is not uncommon and has been amalgamated to form the 'VATER' association, ${ }^{7}$ later expanded to 'VACTERL' when Cardiac and Limb defects were added. ${ }^{89}$

The early diagnosis of these other anomalies is important, not only so that the correct operative approach may be planned but also so that the prognosis for the infant may be assessed, because the mortality and morbidity among infants with oesophageal atresia is directly related to the nature and severity of the other malformations.

\section{Patients and methods}

The records of 253 patients with oesophageal atresia with or without tracheo-oesophageal fistulas treated between January 1980 and December 1987 were retrospectively reviewed. The presence and variety of other anomalies were noted. A comprehensive analysis of these anomalies was carried out and correlated with the type of oesophageal atresia, its management, and the results of treatment. Overall mortality included both early and late deaths.

\section{Results}

Of 253 patients with oesophageal atresia, $122(48 \%)$ had a total of 213 other anomalies. The cardiovascular system was the most commonly affected (61 cases, $29 \%$ ). The second most common group was anorectal malformations (30 cases, $14 \%$ ). The complete range of anomalies is listed in table 1 . The highest incidence ( 13 of $20,65 \%$ ) was in infants who had oesophageal atresia without tracheooesophageal fistula, of whom three had the VATER association. Of 210 infants with oesophageal atresia accompanied by tracheo-oesophageal fistulas, 104 $(50 \%)$ had other anomalies, while only one of 10 patients $(10 \%)$ with $\mathrm{H}$ type tracheo-oesophageal fistulas had other anomalies. Several syndromes have

Table 1 Details of anomalies according to organ system affected

\begin{tabular}{|c|c|c|}
\hline \multirow{2}{*}{$\begin{array}{l}\text { System affected } \\
\text { Cardiovascular }\end{array}$} & \multicolumn{2}{|c|}{$\begin{array}{l}\text { No }(\%) \\
\text { of anomalies }\end{array}$} \\
\hline & 61 & (29) \\
\hline Anorectum & 30 & (14) \\
\hline Genitourinary & 29 & (14) \\
\hline Gastrointestinal (excluding anorectum) & 27 & (13) \\
\hline Vertebral and skeletal & 21 & (10) \\
\hline Respiratory & 13 & (6) \\
\hline Genetic & 8 & (4) \\
\hline Other & 24 & (11) \\
\hline Total & \multicolumn{2}{|c|}{$213(100)$} \\
\hline
\end{tabular}


been identified as being associated with oesophageal atresia (table 2).

Five infants had multiple anomalies that fulfilled the criteria for the CHARGE association (Coloboma, Heart disease, Atresia choanae, Retarded growth and development, Genital hypoplasia, and Ear anomalies or deafness). ${ }^{10}$ Four of them had the common variety of atresia with a distal fistula, and one had oesophageal atresia with proximal and distal fistulas. Two patients had Potter's syndrome (renal agenesis, pulmonary hypoplasia, and dysmorphism with typical facies), two had omphalocoele, cleft lip, cleft palate, and genital hypoplasia, which together constitute the 'SCHISIS' association. ${ }^{11}$

The VACTERL association was present in 25 patients ( $10 \%$ of 253 cases), of whom 18 were boys and seven were girls. Their gestational ages ranged from 29 to 40 weeks (mean 35) and birth weights from 1160 to $3035 \mathrm{~g}$ (mean 2430). The frequency of the various components of VATER or VACTERL association are shown in table 3 .

The other anomalies were the most common causes of mortality in patients with oesophageal atresia with or without tracheo-oesophageal fistulas. Twenty $(32 \cdot 8 \%)$ of the 61 infants with cardiac anomalies died (table 4). Five infants with complex lesions died before undergoing any surgery and 10 died after cardiac operations. It is noteworthy that patients with multiple other anomalies had more complex cardiovascular malformations, which have a higher mortality than the simpler cardiac defects that occur as isolated other anomalies. The latter consisted mainly of ventricular septal defects or persistent patent ductus arteriosus and had a good prognosis.

Table 3 Association of combinations of VACTERL defects and tracheo-oesophageal anomalies

\begin{tabular}{|c|c|c|}
\hline Main VACTERL defects & & $\begin{array}{l}(\%) \\
\text { ases }\end{array}$ \\
\hline Vertebral anomalies & 9 & (36) \\
\hline Anorectal malformations: & 18 & (72) \\
\hline High anomalies & & \\
\hline Intermediate anomaly & & \\
\hline Low anomalies & & \\
\hline Cloacal anomalies & & \\
\hline Tracheo-oesophageal anomalies: & & (100) \\
\hline $\begin{array}{l}\text { Oesophageal atresia with distal } \\
\text { tracheo-oesophageal fistula }\end{array}$ & & \\
\hline $\begin{array}{l}\text { Oesophageal atresia with both proximal and distal } \\
\text { tracheo-oesophageal fistula }\end{array}$ & & \\
\hline $\begin{array}{l}\text { Oesophageal atresia with no tracheo-oesophageal } \\
\text { fistula }\end{array}$ & & \\
\hline Renal anomalies & 14 & (56) \\
\hline Radial dysplasia or aplasia & 3 & (12) \\
\hline Cardiac anomalies & 20 & (80) \\
\hline Limb defects & 7 & (28) \\
\hline Other defects present in VACTERL patients: & 13 & (52) \\
\hline $\begin{array}{l}\text { Duodenal atresia } \\
\text { Malrotation of the intestine }\end{array}$ & & \\
\hline Single umbilical artery & & \\
\hline Omphalocoele & & \\
\hline Pyloric atresia & & \\
\hline Ileal atresia & & \\
\hline Absent right upper lobe of lung & & \\
\hline Polysplenia & & \\
\hline Hypospadias & & \\
\hline High arch palate and mental retardation & & \\
\hline
\end{tabular}

Table 2 Association between complex anomalies and specific syndromes

\begin{tabular}{|c|c|c|c|c|c|c|c|c|c|}
\hline $\begin{array}{l}\text { Type of oesophageal } \\
\text { atresia }\end{array}$ & $\begin{array}{l}\text { VATER } \\
\text { or } \\
\text { VACTERL }\end{array}$ & CHARGE & $\begin{array}{l}\text { Potter's } \\
\text { syndrome }\end{array}$ & $\begin{array}{l}\text { 'SCHISIS' } \\
\text { syndrome }\end{array}$ & $\begin{array}{l}\text { Trisomy } \\
18\end{array}$ & $\begin{array}{l}\text { One or } \\
\text { two } \\
\text { systems } \\
\text { affected }\end{array}$ & $\begin{array}{l}>\text { Two } \\
\text { systems } \\
\text { affected }\end{array}$ & $\begin{array}{l}\text { Total } \\
\text { No }\end{array}$ & $\begin{array}{l}\% \text { Affected } \\
\text { cases } \\
\text { according } \\
\text { to type of } \\
\text { oesophageal } \\
\text { atresia }\end{array}$ \\
\hline
\end{tabular}

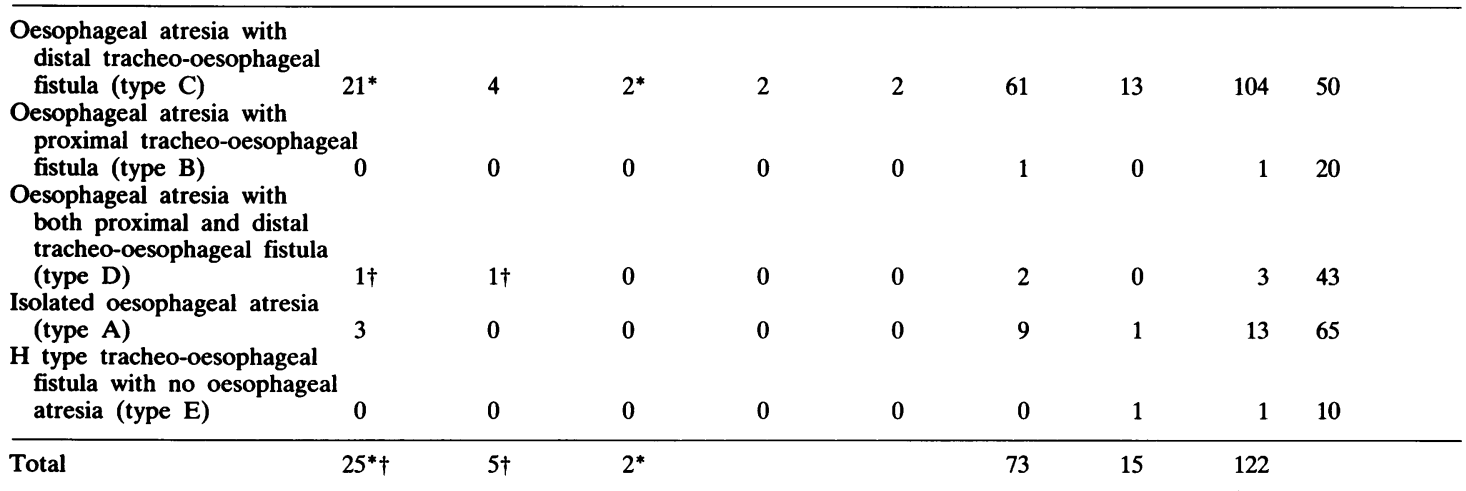

* †One patient had both complex anomalies. 
Table 4 Mortality in patients with cardiovascular anomalies

\begin{tabular}{|c|c|c|}
\hline Cardiovascular defects & $\begin{array}{l}\text { No of } \\
\text { patients }\end{array}$ & $\begin{array}{l}\text { No of } \\
\text { deaths }\end{array}$ \\
\hline Ventricular septal defect & 10 & 1 \\
\hline Patent ductus arteriosus & 7 & 1 \\
\hline Tetralogy of Fallot & 7 & 2 \\
\hline $\begin{array}{l}\text { Ventricular septal defect, patent ductus } \\
\text { arteriosus, and pulmonary stenosis } \\
\text { Ventricular septal defect and patent ductu }\end{array}$ & us 5 & 1 \\
\hline $\begin{array}{l}\text { arteriosus } \\
\text { Atrial septal defect, patent ductus } \\
\text { arteriosus, pulmonary stenosis, and }\end{array}$ & 4 & 1 \\
\hline atrioventricular canal & 4 & 3 \\
\hline Atrial septal defect & 3 & 0 \\
\hline Pulmonary stenosis & 3 & 0 \\
\hline Total anomalous venous drainage & 2 & 2 \\
\hline $\begin{array}{l}\text { Ventricular septal defect, double outlet } \\
\text { right ventricle, and patent ductus } \\
\text { arteriosus }\end{array}$ & 2 & 1 \\
\hline $\begin{array}{l}\text { Ventricular septal defect, patent ductus } \\
\text { arteriosus, and atrial septal defect }\end{array}$ & 2 & 1 \\
\hline $\begin{array}{l}\text { Patent ductus arteriosus, aortopulmonary } \\
\text { window, and aortic stenosis }\end{array}$ & 2 & 0 \\
\hline Transposition of great vessels & 1 & 1 \\
\hline $\begin{array}{l}\text { Single ventricle, patent ductus arteriosus, } \\
\text { and pulmonary stenosis }\end{array}$ & 1 & 0 \\
\hline Hypoplastic heart & 1 & 1 \\
\hline Isolated right sided aortic arch & 4 & 0 \\
\hline Right sided aortic arch and tetralogy of Fallot & t $1^{*}$ & 1 \\
\hline $\begin{array}{l}\text { Right sided aortic arch, patent ductus } \\
\text { arteriosus, ventricular septal defect, and } \\
\text { pulmonary stenosis }\end{array}$ & $2 *$ & 0 \\
\hline Isolated coarctation of the aorta & 1 & 1 \\
\hline $\begin{array}{l}\text { Coarctation of the aorta and atrial } \\
\text { septal defect }\end{array}$ & 1 & 1 \\
\hline $\begin{array}{l}\text { Coarctation of the aorta and ventricular } \\
\text { septal defect }\end{array}$ & 1 & 1 \\
\hline Double aortic arch & 2 & 1 \\
\hline Total & 61 & $20(33 \%)$ \\
\hline
\end{tabular}

${ }^{*}$ Dextrocardia.
Thirty patients had anorectal malformations (14\% of total cases). Six of $20(30 \%)$ of the infants who had oesophageal atresia without tracheooesophageal fistulas were affected compared with 23 of $210(11 \%)$ infants with the more common type of oesophageal atresia and distal tracheooesophageal fistulas (table 5). The incidence of the various types of anorectal malformations and the types of oesophageal atresia are also shown in table 5.

\section{TREATMENT}

Of the 122 patients with oesophageal atresia and other anomalies, no operation was carried out in eight patients because of the complexity of the cardiac malformations or specific syndromes (for example, Potter's or trisomy 18) that were incompatible with survival. Eight infants underwent preliminary gastrostomies and primary repair was delayed in five patients so that their conditions could be stabilised preoperatively. Cardiac anomalies were managed aggressively by either medical or surgical means. The remaining patients $(101,83 \%)$ underwent primary extrapleural repair of the oesophageal defect. The overall survival rate in the 122 patients was $70 \%$.

\section{Discussion}

A total of $122(48 \%)$ of the infants with oesophageal atresia had other congenital anomalies, an incidence that confirms other large reported series. ${ }^{1-6}$ Early failure of midline mesodermal organogenesis resulting in the simultaneous occurrence of multiple defects in various organs has been suggested as an explanation of this phenomenon. ${ }^{78} 12$

Table 5 Association between types of anorectal malformation and types of oesophageal atresia

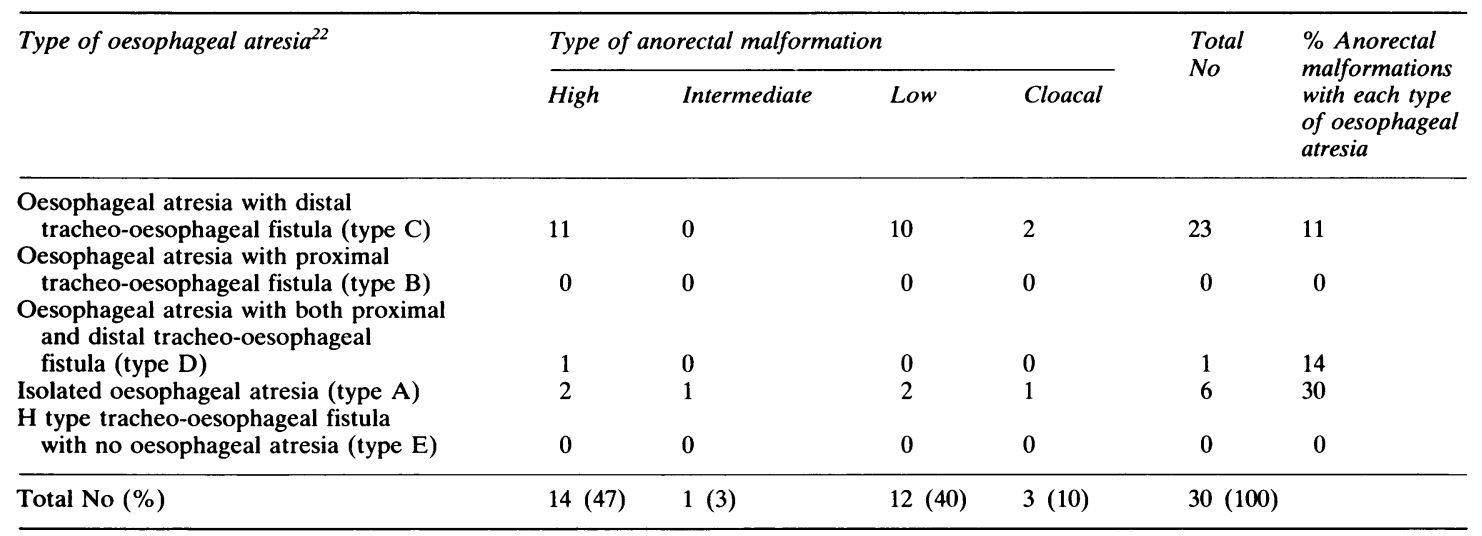


The VATER or VACTERL association is the most widely known variety of multiple mesodermal defects. The tracheo-oesophageal component is present in $20-67 \%$ of patients with the VATER association, ${ }^{1314}$ and $5-17 \%$ of infants with oesophageal atresia fulfill the criteria for the association. ${ }^{51315}$ Other mesodermal defects apart from the VACTERL association may occur and may be collectively referred to as 'axial mesodermal dysplasia'. ${ }^{16}$ The anomalies associated with oesophageal atresia include trisomy $21,{ }^{5} 17$ trisomy 18 (two cases in this series), ${ }^{7}$ Potter's syndrome (two cases in this series),${ }^{14}$ Goldenhar's syndrome, ${ }^{7}$ and duodenal atresia. ${ }^{5} 18$

Khoury et al $^{13}$ used a birth defects surveillance registry of 11366 cases to document the incidence of the six suggested combinations of VATER defects. An increased incidence of certain specific defects occurred in 76 patients with VATER - for example, oral clefts $(n=9)$, omphalocoeles $(n=3)$ and diaphragmatic hernias. They therefore questioned whether the VATER or VACTERL association was one example of a wider range of multiple anomalies. In the series of Weaver et al ${ }^{14}$ of 46 infants with VATER, five had cleft lips or palates. In our series of patients with oesophageal atresia, six had cleft lips or palates and one had an omphalocoele. There were also two other cases that could conform with the 'SCHISIS' association (two or more anomalies including either the neural tube defect, or oral cleft, or omphalocoele, or diaphragmatic hernia) a previously unrecognised association. ${ }^{11}$

Pagon et $a l^{10}$ and Valente and Brereton ${ }^{19}$ reported series of patients with oesophageal atresia and the CHARGE association. Weaver et al $^{14}$ documented two patients with both CHARGE and VATER associations and suggested an association between the two. In our series of infants with oesophageal atresia, five had the CHARGE association, but only one had features of the VATER association.

Infants with oesophageal atresia and other anomalies can be clearly divided into two groups. The first group comprises infants with severe anomalies generally incompatible with survival-for example, trisomy 18, Potter's syndrome, and tracheal agenesis. In our series there were 10 such infants and they all died. In the second group of 112 infants mortality is directly related to the severity of the associated anomalies. Cardiac defects were the most common cause of death and despite aggressive management mortality was high $(33 \%)$. Greenwood and Rosenthal ${ }^{20}$ reported a $79 \%$ mortality in 48 infants with associated cardiovascular lesions in a series of 278 infants with oesophageal atresia. Piekarski and Stephens ${ }^{15}$ reported an increased mortality in infants with oesophageal atresia and anorectal malformations-30\% with one anomaly and $50 \%$ with combined lesions. Even though serious anomalies placed the infants into a higher risk group according to the criteria of Waterson et $a l^{21}$ primary repair was considered wherever possible.

Prompt recognition of any associated anomalies in patients with oesophageal atresia with or. without tracheo-oesophageal fistulas is important, especially cardiovascular defects as these should be treated aggressively. Most of these infants are good candidates for surgical correction and the aim of treatment should be total correction of the various anomalies rather than palliative procedures.

\section{References}

1 Waterston DJ, Cater REB, Aberdeen E. Oesophageal atresia and tracheoesophageal fistula. A study of survival in 218 infants. Lancet 1962;i:819-22.

2 German JC, Mahour HG, Woolley MM. Esophageal atresia and associated anomalies. J Pediatr Surg 1976;11:299-306.

3 Holder TM. Esophageal atresia and tracheoesophageal fistula. In: Ashcraft KW, Holder TM, eds. Pediatric esophageal surgery. Orlando: Grune and Stratton, 1986:29-52.

4 Spitz L, Kiely E, Brereton RJ. Esophageal atresia: five year experience with 148 cases. J Pediatr Surg 1987;22:103-8.

5 Barry JE, Auldist AW. The VATER association-one end of a spectrum of anomalies. Am J Dis Child 1974;128:769-71.

6 Hicks LM, Manfield PB. Esophageal atresia and tracheoesophageal fistula: review of thirteen years' experience. J Thorac Cardiovasc Surg 1981;81:358-63.

7 Quan L, Smith DW. The VATER association. Vertebral defects, Anal atresia, T-E fistula with esophageal atresia, Radial and Renal dysplasia: a spectrum of associated defects. J Pediatr 1973;82:104-7.

8 Temtamy SA, Miller JD. Extending the scope of the VATER association: definition of the VATER syndrome. $J$ Pediatr 1974;85:345-9.

9 Nora AH, Nora JJ. A syndrome of multiple congenital anomalies associated with teratogenic exposure. Arch Environ Health 1975;30:17-21.

10 Pagon RA, Graham JM Jr, Zonana J, Yong SL. Coloboma, congenital heart disease and choanal atresia with multiple anomalies: CHARGE association. J Pediatr 1981;99:223-7.

11 Czeizel A. SCHISIS-association. Am J Med Genet 1981;10: 25-35.

12 Weber TR, Smith W, Grosfeld JL. Surgical experience in infants with VATER association. J Pediatr Surg 1980;15:849-53.

13 Khoury MJ, Cordero JF, Greenberg F, Janes LM, Erickson JD. A population study of the VACTERL association: evidence for its etiologic heterogenicity. Pediatrics 1983;71:815-20.

14 Weaver DD, Mapstone CL, Yu P. The VATER association. Analysis of 46 patients. Am J Dis Child 1986;140:225-9.

15 Piekarski DH, Stephens FD. The association and embryogenesis of tracheoesophageal and anorectal anomalies. Progress in Pediatric Surgery 1976;9:63-76.

16 Russel LJ, Weaver DD, Bull MJ. The axial mesodermal dysplasia spectrum. Pediatrics 1981;67:176-82.

17 Ravinowitz JG, Moseley JE, Mitty HA, Hirschorn K. Trisomy 18 , esophageal atresia, anomalies of the radius and congenital hypoplastic thrombocytopenia. Radiology 1967;89:448.

18 Spitz L, Ali M, Brereton RJ. Combined esophageal and duodenal atresia: experience of 18 patients. J Pediatr Surg 1981;16:4-7.

19 Valente A, Brereton RJ. Oesophageal atresia and the 
368 Chittmittrapap, Spitz, Kiely, and Brereton

CHARGE association. Pediatric Surgery International 1987;2: 93-4.

20 Greenwood RD, Rosenthal A. Cardiovascular malformations associated with tracheoesophageal fistula and esophageal atresia. Pediatrics 1976;57:87-90.

21 Waterson DJ, Carter REB, Aberdeen E. Congenital tracheooesophageal fistula in association with oesophageal atresia. Lancet 1963;ii:55-7.
22 Gross RE. Surgery of infancy and childhood. Philadelphia: WB Saunders, 1953:75-102.

Correspondence to Professor L Spitz, Department of Surgery, Institute of Child Health, 30 Guilford Street, London WC1N 1EH.

Accepted 5 September 1988 